\title{
Result of type a dissecting aortic aneurysms surgical treatment during the 3 years $(2010$ - 2012)
}

\author{
VI Kravchenko ${ }^{1}$, IM Kravchenko ${ }^{1 *}$, LL Sytar ${ }^{1}$, OA Tretyak², OB Larionova ${ }^{3}$, OV Rybakova ${ }^{4}$, YM Tarasenko ${ }^{1}$, \\ GV Knyshov ${ }^{5}$
}

From 23rd World Congress of the World Society of Cardio-Thoracic Surgeons

Split, Croatia. 12-15 September 2013

\section{Background}

Present our experience of surgical treatment of type A TAAD during 2010 - 2012 - the aim of this study.

\section{Methods}

148 consecutive patients with type A TAAD were operated on during $2010-2012$ (122 (82,4\%) males). Their age ranged $20-77$ years, mean 49,3 $\pm 9,6$. Acute (subacute) dissection was in $128(86,5 \%)$, chronic - in $20(13,5 \%)$. The causes of aneurysms forming were: arterial hypertension, atherosclerosis - in 91 (61,5\%); BAV - 18 (12,2\%); MS - 16 (9,8\%); cystomedianecrosis - 16 (10,8\%); blunt aortic injury - in $2(1,4 \%)$ cases, unknown - $5(3,4 \%)$; $96(64,8 \%)$ patients had type I, others $52(35,2 \%)$ - type II according De Bakey classification. The preoperative status included: acute aortic valve insufficiency - 64 (43,2\%); haemopericardium (heart tamponade) - 26 (17,6\%); acute renal insufficiency - $12(8,1 \%)$; left ventricle failure with pulmonary edema - $5(3,4 \%)$; multiorgan failure - $4(2,7 \%)$ patients.

All operations were performed with bypass, mild hypothermia $\left(26-30^{\circ} \mathrm{C}\right), 42(28,4 \%)$ patients with arch injury - deep hypothermia $\left(18-20^{\circ} \mathrm{C}\right)$ and retrograde cerebral perfusion.

We used: supracoronary grafting with valve resuspension- in $98(66,2 \%)$ pts, Bentall-de Bono operation in 48 (32,4\%); David operation in $2(1,4 \%)$.

\section{Results}

Mean blood loss after operation was $519 \pm 82,7 \mathrm{ml}$. Hemorrhage became the reoperation reason in $5(3,4 \%)$ pts. Temporary neurological complications were observed in
$7(4,7 \%)$ pts. There were no difference in deep and mild hypothermia group. Permanent neurological complications were absent. The postoperative 30 days mortality composed $4,7 \%$ (7 patients). All lethal events occurred in the acute dissection group. The reasons of lethal events were: acute renal failure - in $4(2,7 \%)$ patients, hemorragie - in $1(0,7 \%)$ patients, multiorgan failure - in $2(1,3 \%)$.

\section{Conclusion}

Obtained surgical experience, improvement of heart and brain protection in surgical treatment of dissecting aneurysms type A permitted to achieve hospital mortality $4,7 \%$.

\section{Authors' details}

${ }^{1}$ Department of Surgical Treatment of Aortic Pathology, National M. Amosov ICVS NAMS of Ukraine, Kyiv, Ukraine. ${ }^{2}$ Department of Anaestesiology, National M. Amosov ICVS NAMS of Ukraine, Kyiv, Ukraine. ${ }^{3}$ ICU of Department Surgical Treatment of Aortic Pathology, National M. Amosov ICVS NAMS of Ukraine, Kyiv, Ukraine. ${ }^{4}$ Scientific Secretariat, National M. Amosov ICVS NAMS of Ukraine, Kyiv, Ukraine. ${ }^{5}$ Director of National M. Amosov ICVS NAMS of Ukraine, Kyiv, Ukraine.

Published: 11 September 2013

doi:10.1186/1749-8090-8-S1-O25

Cite this article as: Kravchenko et al:: Result of type a dissecting aortic aneurysms surgical treatment during the 3 years (2010 - 2012). Journal of Cardiothoracic Surgery 2013 8(Suppl 1):O25.

\footnotetext{
* Correspondence: kravchenkomd@ukr.net

${ }^{1}$ Department of Surgical Treatment of Aortic Pathology, National M. Amosov ICVS NAMS of Ukraine, Kyiv, Ukraine

Full list of author information is available at the end of the article
} 